\title{
Prevalence of Problematic Mobile Phone Use in British Adolescents
}

\author{
Olatz Lopez-Fernandez, PhD, Luisa Honrubia-Serrano, PhD, \\ Montserrat Freixa-Blanxart, $\mathrm{PhD}{ }^{1}$, and Will Gibson, $\mathrm{PhD}^{2}$
}

\section{Abstract}

The problematic use of mobile phones among adolescents has not been widely studied. There are very few instruments for assessing potential technological addiction to mobile phones, or for categorizing different types of users or uses. The most widely used scale is the Mobile Phone Problem Use Scale (MPPUS), which is used to study adult populations, and has been applied in various forms in international contexts. The aims of this study were to adapt the Spanish version of this scale (MPPUSA) to British adolescents, and then to estimate the prevalence of possible problematic users. A questionnaire was administered to a sample of 1,529 secondary school pupils aged between 11 and 18 years, with 1,026 completed questionnaires being collected. The analysis showed that the factor and construct validity and reliability were comparable to those obtained in previous studies. The prevalence of problematic users among the students was $10 \%$, and the typical problematic user tended to be an adolescent between 11 and 14 years old, studying in a public school, who considered themselves to be an expert user of this technology, who made extensive use of his/her mobile phone, and who attributed the same problem of use among their peers. These users presented notable scores in all the symptoms covered by the scale used to assess problematic use. In conclusion, the adaptation of the MPPUSA as a screening scale for British adolescents presents good sensitivity and specificity for detecting the main addictive symptoms proposed in this validated version.

\section{Introduction}

$\mathbf{T}$ HE TERMS “MOBILE PHONE PROBLEMATIC USE"1,2 (MPPU), "problem cell phone use" ${ }^{3}$ (PCPU), and "mobile phone abuse or addiction" ${ }^{\prime 4}$ have been used to describe patterns of interaction with a mobile phone that have the characteristics of addiction. MPPU is a form of "cyber-disorder," ${ }^{5}$ cyber addiction, $^{2}$ or a behavioral (technological) addiction, ${ }^{3,6-8}$ and is characterized in the repetitive use of the mobile phone to engage in behavior that is known to be counterproductive to health. According to Billieux, ${ }^{2}$ MPPU has been associated with behaviors that include an inability to regulate one's use of the mobile phone, resulting in numerous negative consequences in daily life, including symptoms of dependence, and instances of social, behavioral, and affective problems ${ }^{4}$ within an individual's life. In the fifth edition of the Diagnostic and Statistical Manual of Psychiatric Disorders, the American Psychiatric Association" has recognized the category of "Substance Use and Addictive Disorders," which shows the importance of studying further the applicability of these forms of classification to other areas of technological behavior. This article aims to contribute to our understanding of the prevalence of such forms of behavior in the context of MPPU.

Several researchers ${ }^{2-4,10,11}$ have suggested that MPPU seems to be affecting an increasing number of adolescents and young adults, who dedicate more and more time and attention to using these devices. What remains unclear, however, is the relative use of the many features for which modern mobile phones can be used ${ }^{11-13}$ (e.g., playing games, e-mailing, surfing the web, gambling, listening to music, watching videos, sending real-time chat messages, etc.), and whether or not particular aspects of their application are more common than others. Relatedly, there is an open question about which features of the use might be most related to addictive behavior, or whether the technology itself might be considered addictive. Existing literature reviews $s^{2,4,14}$ have shown that although there has been quite a rapid increase in research related to the MPPU, there is still a lack of conceptual definition related to the behavior and uses, and an absence of a theoretical rationale or of behavioral models that will explain the motivations and

\footnotetext{
${ }^{1}$ Department of Methodology of Behavioural Sciences and Institute for Brain, Cognition and Behaviour, Faculty of Psychology, University of Barcelona, Barcelona, Spain.

${ }^{2}$ Department of Culture, Communication and Media and Doctoral School, Faculty of Children and Learning, Institute of Education, University of London, London, United Kingdom.
} 
underlying mechanisms ${ }^{2}$ which lead to this psychosocial problem. Further, there remains a wide disparity in the adoption of possible diagnostic criteria. ${ }^{2-4}$

Chóliz ${ }^{11}$ suggested that the MPPU in adolescents interfered with their school and personal activities, and led the teenagers to develop relationship social problems. Other extremely concerning symptoms ${ }^{8,12}$ of MPPU are the feelings of withdrawal that can occur in the absence of the device, feelings of loss, signs of craving, tolerance, salience, conflict or functional impairment, relapse, and the resulting loss of control in managing other activities around the mobile phone.

In spite of the increasing interest in this problem, few instruments of assessment have been developed. ${ }^{15}$ Those that are available have involved quite disparate conceptual language to describe the problem, such as dependence, ${ }^{16}$ problem use, ${ }^{1,10,15,17,18}$ excessive use or overuse, ${ }^{14,19,20}$ addictive use, ${ }^{12,21}$ or experiences related with mobile phone use ${ }^{22}$ or mobile phone involvement. ${ }^{23}$ On the whole, the estimated levels of MPPU range from $0 \%$ to $38 \% .{ }^{4}$ This extremely wide range is due to methodological variations in the concepts used to define the problem, the sources of data, the scales of measurement, and the populations sampled. Billieux ${ }^{2}$ has suggested that in order to assess MPPU, researchers should combine semi-structured interviews with validated scales, taking into consideration three aspects: the user's profile of use (e.g., the platform and/or applications being used), the actual levels of daily use (registration of the number of calls made, messages sent, etc.), and the levels of problematic use (scales).

On the whole, MPPU scales that assess adolescents show high internal consistency (Cronbach's $\alpha$ between $0.70^{10}$ and $0.97^{15}$ ) and high validity (factorial, construct, convergent, concurrent, and discriminant). The most widely used scale to date in adults ${ }^{2-26}$ is the Mobile Phone Problem Use Scale (MPPUS), which was developed by Bianchi and Phillips ${ }^{1}$ and is considered a possible "gold standard" 4 in this area. MPPUS has been adapted for use with Chinese teenagers by Leung, ${ }^{12,21}$ while Lopez-Fernandez et al. ${ }^{15}$ recently produced a version for Spanish adolescents. Since 2007, a number of studies focusing on "addiction" to SMS ${ }^{27-29}$ have used the MPPUS in order to establish their construct validity. ${ }^{25}$

However, very few epidemiological studies have been conducted that focus on adolescents' MPPU, despite the fact that this population would seem to be most at risk, due to the poor impulse control that characterizes this developmental stage, as well as the increasing use of mobile phones as a device for the self-management of emotions, social and family life, and social status. ${ }^{30}$ Several studies have been conducted in countries such as Thailand, ${ }^{31}$ China, ${ }^{12,21}$ Korea, $^{19}$ Turkey, ${ }^{10,17}$ Spain, ${ }^{15,20,22,32}$ Italy, ${ }^{33}$ and Australia. ${ }^{23}$ The estimated prevalence of MPPU in adolescence ranges between $5.57 \%$ and $33 \%{ }^{19}$ This diversity in estimate reflects the various scales used in the studies, variations in the concepts being applied, as well as the different sources being used to develop the scales (substance abuse, gambling, and others): the Cellular Phone Dependence Questionnaire $\left(\mathrm{CPDQ}^{16}\right)$, Mobile Phone Addiction Index (MPAI) ${ }^{12,21}$ Excessive Cellular Phone Use Survey $\left(\right.$ ECPUS $\left.^{19}\right)$, Questionnaire of Experiences Related with the Mobile phone ("CERM"22), Problem Cellular Phone Use Questionnaire (PCPU- $\left.\mathrm{Q}^{3}\right)$, Mobile Addiction Test $\left(\mathrm{MAT}^{33}\right)$, Mobile Phone Problem Use Scale for Adolescents
(MPPUSA ${ }^{15}$ ), or ad hoc questionnaires. ${ }^{32}$ Finally, there has been very little categorization of the mechanisms performed to extract the profile of problematic users; those studies that have offered a categorization have not used consistent criteria. Variations include the use of means $(\mathrm{M})$ and standard deviations (SD) for high or low dependency, ${ }^{16}$ the $75^{\text {th }}$ and $25^{\text {th }}$ percentiles for excessive or casual users, ${ }^{20}$ or the upper and lower $30 \%$ to distinguish between excessive and habitual users. ${ }^{19}$ Only one study has tried to establish a cut-off point of the problematic user ${ }^{3}$ by means of classification function.

In the light of the above, the present study had two aims: first, to adapt the MPPUSA for use with British adolescents; and second, to estimate the prevalence of problematic mobile phone use and to define this profile.

\section{Materials and Methods}

\section{Sampling procedure}

A cross-sectional descriptive study was carried out in schools in London, UK, during June 2009 to July 2010. Five secondary schools agreed to participate. The non-random sample comprised 1,529 pupils from public (state) and private schools in different London boroughs, covering both mixed and single-sex education. The invitation to participate ranged from Year 7 to Year 13 (Key Stages 3 or 4 or General Certificate of Secondary Education and Sixth Form/A Level, International Baccalaureate or Cambridge Pre-U).

Permission was sought from the respective head teachers, teachers, and pupils themselves, and confidentiality was ensured in all cases. Formal approval was also given by the ethics committee of Tower Hamlets Research and Performance Development Team, and it was agreed that the procedure would involve administering the pencil-and-paper questionnaire during class time and with the teacher present and an informed consent form for pupils. The participation was voluntary without any reward for participation. The whole of the pupil sample answered the questionnaire, with $85.4 \%$ of the respondents describing themselves as users of a mobile phone, but only $64.6 \%$ as owners of a device. There were different levels of reported ownership between the London boroughs (Tower Hamlets: 54.3\%, Lambeth 63.3\%, and Rickmansworth 88.2\%).

\section{Variables and measures}

The questionnaire had three sections: (a) sociodemographic data, (b) mobile phone use, and (c) the MPPUSA adapted for British adolescents.

The sociodemographic variables recorded were as follows: gender; age (which categorizing pupils into two groupsyoung adolescents, 11-14 years, and older adolescents, 15-18 years); their school year; the school location (London borough); the family size (number of people); and the parents' educational level (elementary, secondary, or higher) and employment status. Participants were asked if they regularly consumed specific drugs ("Do you have any habits such as smoking or drinking?") and if they used other entertainments that did not involve technology ("Do you have any pastime or hobby which does not involve technology?"). They were also asked to indicate their self-perceived level of expertise in the use of this technology (Likert scale from 1= "nonexpert" to $5=$ "highly expert"). 
In terms of their mobile phone use, the respondents were asked if they had a device, how old they were when they received their first mobile phone, if they used it regularly, and what they used it for (to communicate or for entertainment). In addition, they were asked to indicate whether they felt that any of their peers used their mobile phones excessively, and also what they regarded as the most positive and negative aspects of mobile phone use.

The MPPUSA was here adapted for use with British adolescents; it comprises 27 items that are responded to on a 10point Likert scale (from $1=$ "totally false" to $10=$ "completely true"), covering the following symptoms: tolerance, escape from problems, withdrawal, craving, negative life consequences, as well as social motivational aspects. ${ }^{1}$ The adaptation for British adolescents was developed using a back translation procedure (involving both Spanish and British methodologists, linguistic, and educative experts) in order to ensure the cultural and semantic equivalence of the scale items. As a result of this process, 10 items were modified: the wording of six items was adapted to British English (e.g., MPPUS item 21: "There are times when I would rather use the mobile phone than deal with other more pressing issues"; MPPUSA item 20: "There are times when I would rather use my mobile phone than deal with other more urgent matters"), while the content of four was changed to make it suitable for the target population (e.g., MPPUS item 23: "I become irritable if I have to switch off my mobile phone for meetings, dinner engagements, or at the movies"; MPPUSA item 22: "I become irritable if I have to switch off/to silent my mobile phone for classes, meals, or at the cinema").

The results are presented with a confidence interval of $95 \%$. All data processing and analysis was performed using PASW v18.0 for Windows.

\section{Results}

\section{Sample characteristics}

The sample comprised initially 1,529 adolescents, although 1,026 correctly completed the items on the final version of the MPPUSA (see Table 1).

\section{Psychometric study of the MPPUSA adapted for British adolescents}

Factor validity. The factor validity was assessed by means of an exploratory factor analysis (EFA) using the principal components technique. The Kaiser-Mayer-Olkin index $(\mathrm{KMO}=0.98)$ confirmed the adequacy of the sample, while Bartlett's test of sphericity $\left(\chi^{2}{ }_{(351)}=21,339.44 ; p<0.001\right)$ supported the use of the factor analytic procedure. The analysis yielded one factor with eigenvalues greater than 1 , and all the factor loadings were greater than 0.4 , except on item 4 ("All my friends own a mobile phone"), which was consequently eliminated. When EFA was repeated without this item $\left(N=1,026 ; \mathrm{KMO}=0.98, \chi^{2}{ }_{(325)}=21,201.91 ; p<0.001\right)$, the single factor "problem mobile use among British adolescents" explained $56.83 \%$ of the total variance, and therefore could be considered unidimensional. ${ }^{34}$

Item analysis and internal consistency. Table 2 shows the items which obtained the highest scores $(M>4, S D<3.16$; items $1,2,9,10$, and 16) and the lowest scores $(M<2.5$,
TABle 1. SOCIODEMOgRAPHic Characteristics and Descriptive Variables of the Study Sample

$(N=1,026)$ (Percentage, Frequency, Mean, AND Standard Deviation)

\begin{tabular}{|c|c|c|c|}
\hline Variable (n) & $\%(\mathrm{n})$ & M & $\mathrm{SD}$ \\
\hline $\begin{array}{l}\text { Gender } \\
\text { Male } \\
\text { Female }\end{array}$ & $\begin{array}{r}(n=1,024) \\
55(563) \\
45(461)\end{array}$ & & \\
\hline $\begin{array}{l}\text { Age } \\
11-14 \text { years old } \\
15-18 \text { years old }\end{array}$ & $\begin{array}{l}(n=1,001) \\
71.8(719) \\
28.2(282)\end{array}$ & 13.54 & 1.54 \\
\hline $\begin{array}{c}\text { School year } \\
\text { Year } 7 \\
\text { Year } 8 \\
\text { Year } 9 \\
\text { Year } 10 \\
\text { Year } 11 \\
\text { Year } 12 \\
\text { Year } 13\end{array}$ & $\begin{array}{c}(n=1,025) \\
14(144) \\
23.8(244) \\
20.6(211) \\
19.9(204) \\
11.5(118) \\
8.1(83) \\
2(21)\end{array}$ & & \\
\hline $\begin{array}{l}\text { London boroughs of the } \\
\text { schools surveyed } \\
\text { Lambeth } \\
\text { Tower Hamlets } \\
\text { Rickmansworth }\end{array}$ & $\begin{array}{l}(n=1,026) \\
\\
9.4(96) \\
51.9(532) \\
38.8(398)\end{array}$ & & \\
\hline $\begin{array}{l}\text { Family members } \\
\text { (living in main home) } \\
\leq 2 \text { members } \\
\quad \text { (mono-parental family) } \\
3-4 \text { members (traditional family) } \\
\geq 5 \text { members (extensive family) }\end{array}$ & $\begin{array}{l}(n=1,003) \\
\quad 3(30) \\
38.5(386) \\
58.5(587)\end{array}$ & 5.26 & 3.54 \\
\hline $\begin{array}{l}\text { Parents' educational level } \\
\text { Higher education } \\
\text { Medium-low }\end{array}$ & $\begin{array}{c}(n=910) \\
43.6(397) \\
56.4(513)\end{array}$ & & \\
\hline $\begin{array}{l}\text { Parents working } \\
\text { Both } \\
\text { One } \\
\text { None }\end{array}$ & $\begin{array}{l}(n=940) \\
47.3(445) \\
34.8(327) \\
17.9(168)\end{array}$ & & \\
\hline $\begin{array}{l}\text { Tobacco/alcohol habitual } \\
\text { consumption } \\
\text { Yes } \\
\text { No }\end{array}$ & $\begin{array}{l}(n=1,019) \\
15.6(159) \\
84.4(860)\end{array}$ & & \\
\hline $\begin{array}{l}\text { Entertainment without technology } \\
\text { Yes } \\
\text { No }\end{array}$ & $\begin{array}{l}(n=1,009) \\
73.1(738) \\
26.9(271)\end{array}$ & & \\
\hline $\begin{array}{l}\text { Degree of expertise } \\
\text { Non-expert } \\
\text { Rather good } \\
\text { Quite good } \\
\text { Expert } \\
\text { Highly expert }\end{array}$ & $\begin{array}{c}(n=975) \\
1.9(19) \\
15.7(153) \\
40.4(394) \\
24.5(239) \\
17.4(170)\end{array}$ & & \\
\hline
\end{tabular}

$S D<2.46$; items 14 and 18). According to homogeneity indices, all items showed a high correlation with the corrected total score ( $>0.6)$; the MPPUSA has an excellent internal consistency (Cronbach's $\alpha=0.97$ ).

Construct validity. The total possible score on the MPPUSA ranges from 26 to $260(M=85.18, M d n=67$, $S D=57.29$ ), with higher scores being indicative of more problematic use for 1,026 British adolescents. Regarding their perceptions of problematic mobile phone use, those who said they noticed the problem among their peers $(N=1,050: 89.9 \%$; 


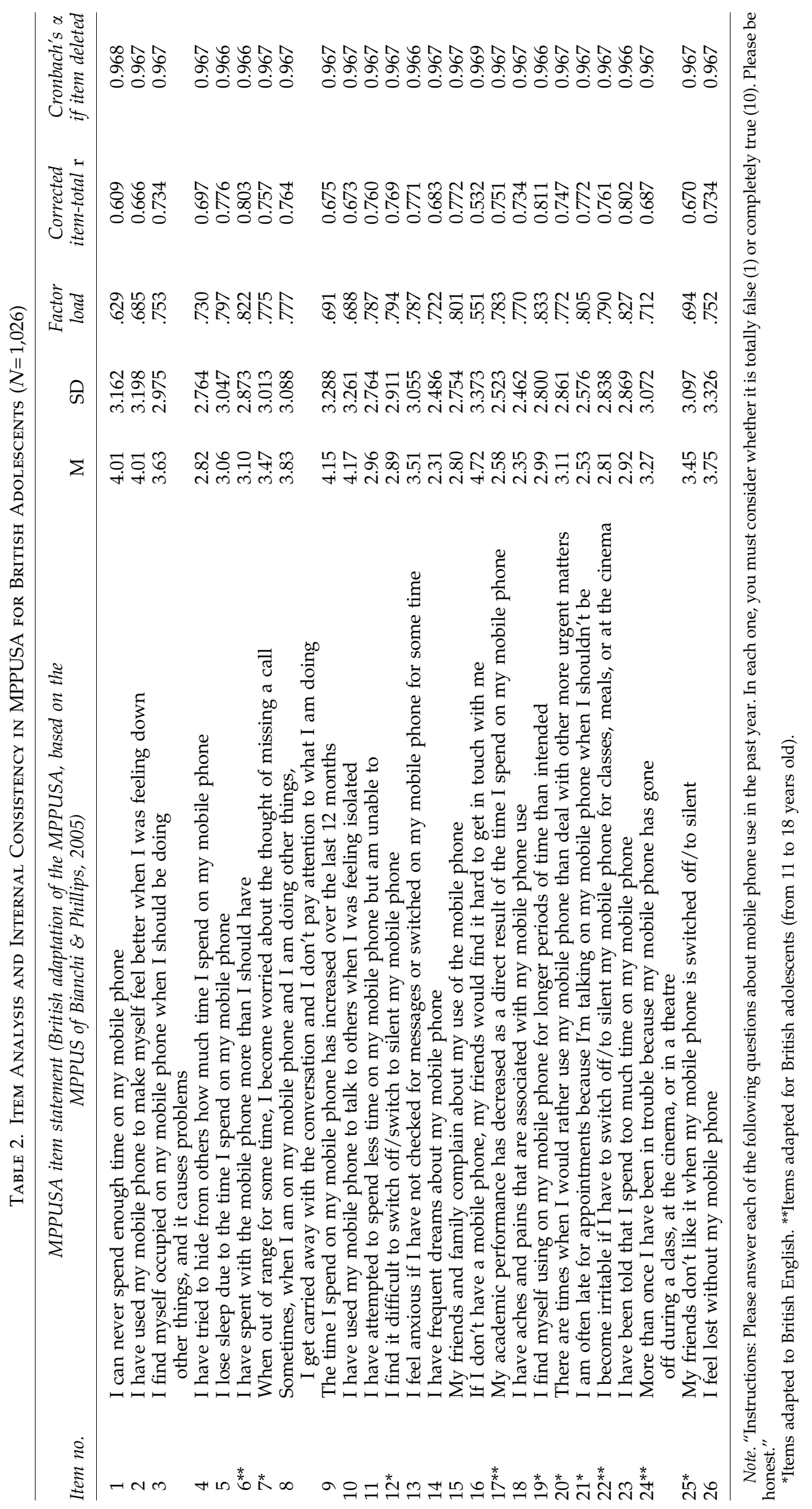


Mdn =67.5) obtained a higher median score than did those who reported no such observation $(10.1 \%$; $M d n=56.50$; $U=15,882 ; Z=2.42, p<0.05, r=0.09$ ). Moreover, their own perception of MPPU showed that those who said they noticed the problematic use $(N=1,231: 26.60 \%$; $M d n=114)$ obtained a higher median score than did those who reported no problem (73.40\%; Mdn=60; $U=49,009 ; Z=9.66, p<0.001, r=0.32$ ).

\section{Profile of problematic user according to the MPPUSA}

Problematic use was classified according to the statistical criteria used in the literature on gambling addiction. ${ }^{35}$ Specifically, the $15 \mathrm{th}, 80^{\text {th }}$, and 90 th percentiles are used to classify occasional use, habitual use, at risk, and problematic use respectively. In the present study, these categories correspond to scores of 30,131, and 167 on the MPPUSA. The analysis revealed that $14.1 \%$ of participants were occasional users $(\mathrm{Mdn}=26), 65.3 \%$ were habitual users $(\mathrm{Mdn}=62)$, $10.5 \%$ were at risk of problematic use $(\mathrm{Mdn}=143)$, and $10 \%$ were problematic users $(\mathrm{Mdn}=197)$. There were significant differences between the four categories $\left(H: Z_{(3)}=735.70\right.$, $p<0.001)$, as well as between each pair, thereby demonstrating the suitability of the categorization. Following the literature on problematic Internet use, $20.5 \%$ of participants could be considered as potential problematic users (combination of the at risk and problem categories).

Among those classified as problematic users $(n=103)$, almost all variables were equivalent in their values, except $65.7 \%$ belonged to the younger age group, $85.4 \%$ studying between Year 8 and Year 11, 70.9\% in public schools, $64.9 \%$ with parents without university studies, $63.1 \%$ did not consume alcohol and/or tobacco, $64.3 \%$ considered themselves to be between fairly and highly expert in the use of mobile phone, and $87.9 \%$ used it for all kinds of purposes. However, $52 \%$ of these adolescents said that their mobile phone use could affect them in some way, and $95.6 \%$ noticed problematic use among their peers. Moreover, they reported using mobile phones above all for communication (70.7\%) and to a lesser extent for entertainment (19.5\%). They also described using their mobile phones for solving urgent problems. The respondents in this category pointed to possible addiction $(32.4 \%)$, misuse $(23.5 \%)$, and health problems $(17.6 \%)$ as the main negative effect, with cost and wasting time also being identified $(26.5 \%)$. It should also be noted that those who were classified as problematic users obtained a median score above 7 in all the items (see Table 3) with MPPUSA $(M=208.15, M d n=197, S D=33.55)$.

A tentative statistical verification of our suggested cut-off score of 167 (e.g., separating problematic users from nonproblematic users) was used to calculate the sensitivity, specificity, and classification accuracy of the symptoms proposed in this study on the MPPUSA. This is a process that has also been used in other Internet problematic use studies. ${ }^{36}$ Following this, we found the average of each symptom, and then calculated the percentage agreement, counting the number of participants who gave a rating of 6 or higher to each symptom (a process that has also been used in previous MPPUS study ${ }^{37}$ ). As could be observed (see Table 4), the sensitivity and the specificity are important ${ }^{38}$ in all the symptoms proposed for the authors to provide a better description of this MPPUSA adaptation in relation of the items which we consider evaluate each addictive symptom (toler- ance, escape from problems, withdrawal, craving, negative consequences and social motivations).

Finally, a subsample of 103 nonproblematic users was randomly extracted in order to compare them with the group of problematic users. In our proposal of grouping items that represent each symptom, statistical differences were observed between both groups (see Table 5).

\section{Discussion}

This new form of the MPPUSA shows greater reliability than the original MPPUS ${ }^{1}$ and identical reliability to its previous Spanish version. ${ }^{15}$ The factor and construct validity of the questionnaire were consistent with a unidimensional model, ${ }^{34}$ although other possible analyses could be undertaken in the future to guarantee different types of validity. As with the Spanish version, it was necessary to eliminate the originally item 4 in MPPUS, which was consistent with Phillips et al. ${ }^{37}$ When comparing the MPPUS results ${ }^{1,37}$ with our findings, it is notable that the scores in adults (MPPUS) are lower than in adolescents (MPPUSA). Moreover, it has been observed that several items have obtained high averages in both versions (e.g., item 2 among others). Likewise, in our study, two items obtained the lowest averages (e.g., items 14 and 18), which possibly indicates the necessity to revise them in future versions for adolescents.

The problematic users show higher scores in almost all the items (except 14 and 18). Nevertheless, a clear profile of mobile phone problematic user was not observed. Thus, even though a restrictive statistical criterion was used here, the estimated prevalence of these British adolescents classified as problematic users was $10 \%$, which is within the range of previous European studies. ${ }^{22,32,33}$ When considering prevalence, however, it is important to bear in mind the diversity of instruments and classification criteria that have been used to date, which makes the comparability of the findings difficult.

The comparison between the scores obtained from the problematic users in each one of the symptoms that reflects the MPPUSA shows important differences with those obtained for the nonproblematic users. These results, together with the good sensitivity and specificity, could indicate the utility of the scale in screening studies that are used to measure whether an adolescent could develop a MPPU. However, the presence of the symptoms that we studied is based on our proposal to MPPUSA. Thus, more research is required to validate these symptoms clinically. With respect to the statistical analyses of function classification, it would therefore be interesting to conduct a study whose methodology was able to evaluate other procedures (e.g., receiver-operating characteristic curves) and predictive values, among other criteria traditionally used to assess a test's predictive capacity. However, this kind of analysis would ideally require the use of diagnostic criteria established by clinical professionals, something that, according to our literature search, nobody has yet achieved even though its importance has been flagged. ${ }^{3}$ We agree, in line with researchers from Kaohsiung Medical University (Taiwan), ${ }^{3,39,40}$ that it is necessary to investigate how to establish cut-off points based on the mental health criteria associated with this behavioral problem. These should be clinically validated in order to achieve the possibility of offering scales to diagnose. ${ }^{2}$ 
Table 3. Descriptive MPPUSA for Problematic Users $(N=103)$

\begin{tabular}{|c|c|c|c|c|c|c|c|c|}
\hline Item & MPPUSA item statement (British adaptation) & M & $M d n$ & Mo & SD & Range & Min. & Max. \\
\hline 1 & I can never spend enough time on my mobile phone & 8.29 & 10 & 10 & 2.62 & 9 & 1 & 10 \\
\hline 2 & $\begin{array}{l}\text { I have used my mobile phone to make myself feel better } \\
\text { when I was feeling down }\end{array}$ & 8.38 & 10 & 10 & 2.34 & 9 & 1 & 10 \\
\hline 3 & $\begin{array}{l}\text { I find myself occupied on my mobile phone when I should be doing } \\
\text { other things, and it causes problems }\end{array}$ & 8.27 & 10 & 10 & 2.36 & 9 & 1 & 10 \\
\hline 4 & $\begin{array}{l}\text { I have tried to hide from others how much time I spend } \\
\text { on my mobile phone }\end{array}$ & 7.25 & 8 & 10 & 3.22 & 9 & 1 & 10 \\
\hline 5 & I lose sleep due to the time I spend on my mobile phone & 8.64 & 10 & 10 & 1.97 & 9 & 1 & 10 \\
\hline 6 & I have spent with the mobile phone more than I should have & 8.39 & 9 & 10 & 2.09 & 9 & 1 & 10 \\
\hline 7 & $\begin{array}{l}\text { When out of range for some time, I become worried about } \\
\text { the thought of missing a call }\end{array}$ & 8.45 & 10 & 10 & 1.91 & 8 & 2 & 10 \\
\hline 8 & $\begin{array}{l}\text { Sometimes, when I am on my mobile phone and I am doing other things, } \\
\text { I get carried away with the conversation and I don't pay attention } \\
\text { to what I am doing }\end{array}$ & 8.83 & 10 & 10 & 1.67 & 7 & 3 & 10 \\
\hline 9 & The time I spend on my mobile phone has increased over the last 12 months & 8.53 & 10 & 10 & 2.19 & 9 & 1 & 10 \\
\hline 10 & I have used my mobile phone to talk to others when I was feeling isolated & 8.66 & 10 & 10 & 1.94 & 8 & 2 & 10 \\
\hline 11 & I have attempted to spend less time on my mobile phone but am unable to & 7.91 & 8 & 10 & 2.49 & 9 & 1 & 10 \\
\hline 12 & I find it difficult to switch off/switch to silent my mobile phone & 8.24 & 9 & 10 & 2.38 & 9 & 1 & 10 \\
\hline 13 & $\begin{array}{l}\text { I feel anxious if I have not checked for messages or switched } \\
\text { on my mobile phone for some time }\end{array}$ & 8.55 & 10 & 10 & 1.85 & 9 & 1 & 10 \\
\hline 14 & I have frequent dreams about my mobile phone & 6.35 & 7 & 10 & 3.63 & 9 & 1 & 10 \\
\hline 15 & My friends and family complain about my use of the mobile phone & 7.79 & 9 & 10 & 2.66 & 9 & 1 & 10 \\
\hline 16 & $\begin{array}{l}\text { If I don't have a mobile phone, my friends would find it hard } \\
\text { to get in touch with me }\end{array}$ & 8.60 & 10 & 10 & 2.05 & 9 & 1 & 10 \\
\hline 17 & $\begin{array}{l}\text { My academic performance has decreased as a direct result of the time } \\
\text { I spend on my mobile phone }\end{array}$ & 6.82 & 7 & 10 & 3.16 & 9 & 1 & 10 \\
\hline 18 & I have aches and pains that are associated with my mobile phone use & 6.45 & 7 & 10 & 2.41 & 9 & 1 & 10 \\
\hline 19 & $\begin{array}{l}\text { I find myself using on my mobile phone for longer periods } \\
\text { of time than intended }\end{array}$ & 8.20 & 7 & 10 & 3.48 & 9 & 1 & 10 \\
\hline 20 & $\begin{array}{l}\text { There are times when I would rather use my mobile phone than deal } \\
\text { with other more urgent matters }\end{array}$ & 8.05 & 9 & 10 & 2.47 & 9 & 1 & 10 \\
\hline 21 & $\begin{array}{l}\text { I am often late for appointments because I'm talking on my mobile } \\
\text { phone when I shouldn't be }\end{array}$ & 7.13 & 8 & 10 & 3.10 & 9 & 1 & 10 \\
\hline 22 & $\begin{array}{l}\text { I become irritable if I have to switch off/to silent my mobile phone } \\
\text { for classes, meals, or at the cinema }\end{array}$ & 7.89 & 9 & 10 & 2.49 & 9 & 1 & 10 \\
\hline 23 & I have been told that I spend too much time on my mobile phone & 8.05 & 9 & 10 & 2.58 & 9 & 1 & 10 \\
\hline 24 & $\begin{array}{l}\text { More than once I have been in trouble because my mobile phone has gone } \\
\text { off during a class, at the cinema, or in a theatre }\end{array}$ & 7.83 & 9 & 10 & 2.75 & 9 & 1 & 10 \\
\hline 25 & My friends don't like it when my mobile phone is switched off/to silent & 7.84 & 9 & 10 & 2.57 & 9 & 1 & 10 \\
\hline 26 & I feel lost without my mobile phone & 8.79 & 10 & 10 & 1.84 & 9 & 1 & 10 \\
\hline
\end{tabular}

Table 4. Proposal of the Classification Function of the MPPUSA $(N=1,026)$

\begin{tabular}{|c|c|c|c|c|c|c|c|c|c|}
\hline \multirow[b]{2}{*}{ Symptoms } & \multicolumn{3}{|c|}{$\begin{array}{c}\text { Answers of nonproblematic } \\
\text { users }(\mathrm{n}=923)\end{array}$} & \multicolumn{3}{|c|}{$\begin{array}{c}\text { Answers of problematic } \\
\text { users }(\mathrm{n}=103)\end{array}$} & \multirow[b]{2}{*}{ Sensitivity } & \multirow[b]{2}{*}{ Specificity } & \multirow[b]{2}{*}{$\begin{array}{c}\text { Classification } \\
\text { accuracy }\end{array}$} \\
\hline & $\begin{array}{c}\mathrm{M} \\
(\mathrm{SD})\end{array}$ & $\begin{array}{c}\mathrm{n} \\
Y e s\end{array}$ & $\begin{array}{c}\mathrm{n} \\
\text { No }\end{array}$ & $\begin{array}{c}\mathrm{M} \\
(\mathrm{SD})\end{array}$ & $\begin{array}{c}\mathrm{n} \\
Y e s\end{array}$ & $\begin{array}{c}\mathrm{n} \\
\text { No }\end{array}$ & & & \\
\hline Tolerance: items 1, 9, and 19 (11.54\%) & $3.20(2.03)$ & 113 & 810 & $8.34(1.80)$ & 96 & 7 & 93.20 & 87.76 & 88.30 \\
\hline $\begin{array}{l}\text { Escape from problems: items } \\
2,10 \text {, and } 20(11.54 \%)\end{array}$ & $3.25(2.07)$ & 120 & 803 & $8.36(1.61)$ & 97 & 6 & 94.17 & 87.00 & 87.72 \\
\hline $\begin{array}{l}\text { Withdrawal: items } 7,12 \text {, } \\
\text { and } 26(11.54 \%)\end{array}$ & $2.80(2.07)$ & 98 & 825 & $8.49(1.56)$ & 99 & 4 & 96.12 & 89.38 & 90.1 \\
\hline Craving: items 11, 13, and 22 (11.54\%) & $2.53(1.84)$ & 66 & 857 & $8.12(1.72)$ & 93 & 10 & 90.30 & 92.85 & 92.59 \\
\hline $\begin{array}{l}\text { Negative consequences: items } \\
3,4,5,6,8,14,15,17,18,21 \\
23 \text {, and } 24(46.15 \%)\end{array}$ & $2.41(1.55)$ & 25 & 898 & $7.65(1.57)$ & 90 & 13 & 87.38 & 97.29 & 96.30 \\
\hline $\begin{array}{l}\text { Social motivations: items } \\
16 \text { and } 25(7.69 \%)\end{array}$ & $3.62(2.42)$ & 160 & 763 & $8.22(1.89)$ & 90 & 13 & 87.38 & 82.67 & 83.14 \\
\hline
\end{tabular}

Note. The MPPUSA symptoms analyzed belong to authors' proposal done specifically for this study. It describes the groupings of items that conform to each symptom, as well as the proportion of each symptom expressed as a percentage between parentheses. 
Table 5. Comparison of Problematic and Nonproblematic Users (Randomly Selected) in Relation to Each Symptom in the MPPUSA Through ManN-Whitney Test

\begin{tabular}{|c|c|c|c|c|c|c|}
\hline Symptoms & $\begin{array}{c}\text { Nonproblematic } \\
\text { users }(\mathrm{n}=103) M d n\end{array}$ & $\begin{array}{c}\text { Problematic } \\
\text { users }(\mathrm{n}=103) M d n\end{array}$ & $\mathrm{U}$ & $\mathrm{Z}$ & $\mathrm{p}$ & $\mathrm{r}$ \\
\hline 1. Tolerance & 3.33 & 8.33 & 601.50 & 11.04 & $<0.001$ & 0.77 \\
\hline 2. Escape from problems & 3.67 & 8.33 & 544.50 & 11.16 & $<0.001$ & 0.78 \\
\hline 3. Withdrawal & 2.67 & 9 & 627.00 & 11.01 & $<0.001$ & 0.77 \\
\hline 4. Craving & 2.00 & 8.00 & 395.00 & 11.54 & $<0.001$ & 0.80 \\
\hline 5. Negative consequences & 1.92 & 7.42 & 121.00 & 12.13 & $<0.001$ & 0.85 \\
\hline 6. Social motivations & 4.00 & 8.50 & 152.50 & 9.77 & $<0.001$ & 0.68 \\
\hline
\end{tabular}

One particularly interesting finding is that in current studies of MPPU, ${ }^{3,23}$ withdrawal seem to be the most relevant symptom of addiction. This was also found to be the case in our study - the adolescents reported experiencing unpleasant emotions when they were unable to use their mobile phone as usual. $^{8,23}$ Another finding to highlight is that the greater the level of problematic use, the more likely the adolescent is to notice the same problem among his or her peers, which may suggest that problematic users have some insight into their own behavioral problems. Alternatively, it could simply indicate that the perception of MPPU is overestimated in others. ${ }^{4}$ We would argue, however, that more research is needed before the MPPU can be considered as a diagnostic category, even though some authors ${ }^{11}$ do regard it as a clinical entity.

To conclude, the use of mobile phones seems to be an intrinsic part of young people's lives, one that is reinforced through the self- and social gratification it provides, ${ }^{41,42}$ and which also enables young people to manage their own emotions and behavior. ${ }^{20,22,24}$ Given the current availability of Internet-enabled mobile phones as tools for communication and entertainment among adolescents, research is needed that addresses the use of these smartphones, which may lead to more use overall, ${ }^{43}$ as well as to addictive behaviors that can be associated with problematic use.

\section{Acknowledgments}

The authors would like to thank Jim Phillips for his permission to adapt the MPPUS and his valuable support. We are also grateful to the head teachers, teachers, and pupils from the London schools that participated: Rickmansworth School (Daniel Needlestone, ICT teacher), London Nautical School (Morlette Lindsay, Lecturer in English Education in the Culture, Communication and Media Department, Institute of Education (IoE), University of London (UoL)), Mulberry School for Girls (Ian James, Deputy Head Teacher), Stepney Green Maths, Computing \& Science College (Paul Copson, Assistant Head Teacher), and George Green's School (Jennifer Surujpaul, Head of ICT Faculty and E-Learning). For their help in establishing these contacts, we would also like to thank Niki E. Davis (Professor of e-Learning and President of DEANZ, University of Canterbury, New Zealand), Christina Preston (President of Mirandanet, United Kingdom), and Terry Patterson (Head of e-Learning in Tower Hamlets Children, Schools and Families Directorate). The fieldwork could not have been undertaken without the support of Andrew Brown (Director of the Doctoral School, IoE, UoL). The study was funded through grant 2009 BE1 00394, from the "Agència de Gestió d'Ajuts Universitaris i de Re- cerca," Catalan government (Generalitat de Catalunya), and the translation was funded for the "Col-legi Oficial de Psicòlegs de Catalunya" (COPC). Finally, we would like to extend our thanks to the reviewers for their suggestions, which have improved this work considerably.

\section{Author Disclosure Statement}

No competing financial interests exist.

\section{References}

1. Bianchi A, Phillips J. Psychological predictors of problem mobile phone use. CyberPsychology \& Behavior 2005; 8: 39-51.

2. Billieux J. Problematic use of the mobile phone: a literature review and a pathways model. Current Psychiatry Reviews 2012; 8:299-307.

3. Yen C, Tang T, Ko C, et al. Symptoms of problematic cellular phone use, functional impairment and its association with depression among adolescents in Southern Taiwan. Journal of Adolescence 2009; 32:863-873.

4. Pedrero Pérez EJ, Rodríguez Monje MT, Ruiz Sánchez De León JM. Mobile phone abuse or addiction. A review of the literature. Adicciones 2012; 24:139-152.

5. Young K, Pistner M, O'Mara J, et al. Cyber disorders: the mental health concern for the new millennium. CyberPsychology \& Behavior 1999; 2:475-479.

6. Marks I. Behavioural (non-chemical) addictions. British Journal of Addiction 1990; 85:1389-1394.

7. Grant J, Potenza M, Weinstein A, et al. Introduction to behavioral addictions. The American Journal of Drug \& Alcohol Abuse 2010; 36:233-241.

8. Griffiths M. Does Internet and computer "addiction" exist? Some case study evidence. CyberPsychology \& Behavior 2000; 3:211-218.

9. American Psychiatric Association. (2013) DSM-5 development. www.dsm5.org/Pages/Default.aspx (accessed May 9, 2013).

10. Güzeller C, Coşguner T. Development of a problematic mobile phone use scale for Turkish adolescents. CyberPsychology, Behavior, \& Social Networking 2012; 15:205-211.

11. Chóliz M. Mobile phone addiction: a point of issue. Addiction 2010; 105:373-374.

12. Leung L. Linking psychological attributes to addiction and improper use of the mobile phone among adolescents in Hong Kong. Journal of Children \& Media 2008; 2:93-113.

13. Zulkefly SN, Baharudin, R. Mobile phone use amongst students in a university of Malaysia: its correlates and relation to psychological health. European Journal of Scientific Research 2009; 37:206-218. 
14. Sánchez-Carbonell X, Beranuy $M$, Castellana $M$, et al. Internet and cell phone addiction: passing fad or disorder? Adicciones 2009; 20:149-160.

15. Lopez-Fernandez O, Honrubia-Serrano ML, Freixa-Blanxart, M. Spanish adaptation of the "Mobile Phone Problem Use Scale" for adolescent population. Adicciones 2012; 24:123-130.

16. Toda M, Monden K, Kubo K, et al. Cellular phone dependence tendency of female university students. Nihon Eiseigaku Zasshi. Japanese Journal of Hygiene 2004; 59:383-386.

17. Güzeller CO, Coşguner T. Development of a problematic mobile phone use scale for Turkish adolescents. CyberPsychology, Behavior, \& Social Networking 2012; 15:205-211.

18. Billieux J, Linden M, Rochat L. The role of impulsivity in actual and problematic use of the mobile phone. Applied Cognitive Psychology 2008; 22:1195-1210.

19. Ha J, Chin B, Park D, et al. Characteristics of excessive cellular phone use in Korean adolescents. CyberPsychology \& Behavior 2008; 11:783-784.

20. Jenaro C, Flores N, Gómez-Vela M, et al. Problematic Internet and cell-phone use: psychological behavioral, and health correlates. Addiction Research \& Theory 2007; 15:309-320.

21. Leung L. (2008) Leisure boredom, sensation seeking, selfesteem, addiction symptoms and patterns of mobile phone use. In Korini E, Utz S, Tanis M, Barnes S, eds. Mediated interpersonal communication. New York: Routledge, pp. 359-381.

22. Fargues M, Lusar A, Jordania C, et al. Validación de dos escalas breves para evaluar la adicción a Internet y el abuso de móvil. Psicothema 2009; 21:480-485.

23. Walsh SP, White KM, Young R McD. Needing to connect: the effect of self and others on young people's involvement with their mobile phones. Australian Journal of Psychology 2010; 62:194-203.

24. Laramie D. (2007) Emotional and behavioral aspects of mobile phone use [ebook]. ProQuest Information \& Learning.

25. Rutland J, Sheets T, Young T. Development of a scale to measure problem use of short message service: the SMS Problem Use Diagnostic Questionnaire. CyberPsychology \& Behavior 2007; 10:841-843.

26. Takao M, Takahashi S, Kitamura M. Addictive personality and problematic mobile phone use. CyberPsychology \& Behavior 2009; 12:501-507.

27. Igarashi $\mathrm{T}$, Motoyoshi $\mathrm{T}$, Takai J, et al. No mobile, no life: self-perception and text-message dependency among Japanese high school students. Computers In Human Behavior 2008;24:2311-2324.

28. Lu X, Watanabe J, Liu Q, et al. Internet and mobile phone text-messaging dependency: factor structure and correlation with dysphoric mood among Japanese adults. Computers in Human Behavior 2011; 27:1702-1709.

29. Perry S, Lee K. Mobile phone text messaging overuse among developing world university students. Communicatio: South African Journal for Communication Theory \& Research 2007; 33:63-79.

30. Muñoz-Rivas M, Agustin S. La adicción al teléfono móvil. Psicología Conductual Revista Internacional De Psicología Clínica De La Salud 2005; 13:481-493.
31. Kawasaki N, Tanei S, Tanada S, et al. Survey on cellular phone usage on students in Thailand. Journal of Physiological Anthropology 2006; 25:377-382.

32. Sánchez-Martínez M, Otero A. Factors associated with cell phone use in adolescents in the community of Madrid (Spain). CyberPsychology \& Behavior 2009; 12:131-137.

33. Martinotti G, Villella C, La Torre G, et al. Problematic mobile phone use in adolescence: a cross-sectional study. Journal of Public Health 2011; 19:545-551.

34. Reckase M. Unifactor latent trait models applied to multifactor tests: results and implications. Journal of Educational Statistics 1979; 4:207-230.

35. Chow S, Leung G, Ng C, et al. A screen for identifying maladaptive Internet use. International Journal of Mental Health \& Addiction 2009; 7:324-332.

36. Siomos K, Dafouli E, Braimiotis D, et al. Internet addiction among Greek adolescent students. CyberPsychology \& Behavior 2008; 11:653-657.

37. Phillips JG, Saling L, Blaszczynski A. (2008) Psychology of mobile phone use and misuse. In Harper AC, Buress RV, eds. Mobile telephones: networks, applications, and performance. New York: Nova, pp. 191-210.

38. Löwe B, Spitzer R, Herzog W, et al. Comparative validity of three screening questionnaires for DSM-IV depressive disorders and physicians' diagnoses. Journal of Affective Disorders 2004; 78:131-140.

39. Ko C, Yen J, Chen C, et al. Proposed diagnostic criteria of Internet addiction for adolescents. Journal of Nervous \& Mental Disease 2005; 193:728-733.

40. Ko C, Yen J, Yen C, et al. Screening for Internet addiction: an empirical study on cut-off points for the Chen Internet Addiction Scale. The Kaohsiung Journal of Medical Sciences 2005; 21:545-551.

41. Chóliz M, Villanueva V, Chóliz MC. Ellas, ellos y su móvil: Uso, abuso (¿y dependencia?) del teléfono móvil en la adolescencia. Revista española de drogodependencias 2009; 1:74-88.

42. Walsh SP, White KM, Young RM. Over-connected? A qualitative exploration of the relationship between Australian youth and their mobile phones. Journal of Adolescence 2008; 31:77-92.

43. Oulasvirta A, Rattenbury T, Ma L, et al. Habits make smartphone use more pervasive. Personal \& Ubiquitous Computing 2012; 16:105-114.

Address correspondence to:

Dr. Olatz López-Fernández

Department of Methodology of Behavioural Sciences and Institute for Brain, Cognition and Behaviour

Faculty of Psychology

University of Barcelona

Campus Mundet, Edifici Ponent

Passeig de la Vall d'Hebron, 171

08035 Barcelona

Spain

E-mail: olatzlopez@ub.edu; lopez.olatz@gmail.com 